www.jmscr.igmpublication.org

Impact Factor 5.84

Index Copernicus Value: 71.58

ISSN (e)-2347-176x ISSN (p) 2455-0450

crossref DOI: _https://dx.doi.org/10.18535/jmscr/v6i1.157

Journal Of Medical Science And Clinical Research

IGM Publication

An Official Publication of IGM Publication

\title{
Detection and Characterization of Kaposi's sarcoma Herpes Virus (KSHV) from Archival Tissues fixed in Formalin and Paraffin Wax-Embedded at Kenyatta National Hospital, Kenya
}

\section{Rodgers N. Demba ${ }^{1,2 *}$, Nathan Shaviya ${ }^{3}$, Matilu Mwau ${ }^{4}$, Walter Mwanda ${ }^{2}$}

${ }^{1}$ School of Health Sciences, Kisii University, P.O Box 408-40200, Kisii, Kenya

${ }^{2}$ University of Nairobi Institute of Tropical and infectious Diseases,P.O. Box 30197, GPO, Nairobi, Kenya

${ }^{3}$ Masinde Muliro University of Science and Technology, P. O Box 190-50100 Kakamega, Kenya

${ }^{4}$ Kenya Medical Research Institute (KEMRI) Centre for Infectious and Parasitic Diseases Control Research

(CIPDCR) P.O. Box 3- 50400 Busia, Kenya

Email:dembanorman@gmail.com ${ }^{1,2^{*}}$, shavianathan@gmail.com ${ }^{3}$, matilu.mwau@gmail.com ${ }^{4}$ walter.mwanda@uonbi.ac.ke ${ }^{2}$

Corresponding Author

Rodgers N. Demba

School of Health Sciences, Kisii University, P.O Box 408-40200, Kisii, Kenya

University of Nairobi Institute of Tropical and infectious Diseases, P.O. Box 30197, GPO, Nairobi, Kenya

\section{Abstract}

The DNA of Human Herpes virus (HHV-8) has been detected in patients with HIV/AIDS (Human Immunodeficiency Virus/Acquired Immunodeficiency Disease). Kaposi's sarcoma (KS) is a cancer seen in patients who have developed immunosuppression due to HIV. In order to characterize KS, archived tissues fixed in formalin and paraffin wax-embedded were obtained and three distinct gene region were determined by PCR (Polymerase chain reaction) and sequencing: K1, K15 and ORF75. The results showed that the three targeted gene were distinct and were present in the archived samples. The total number of the archived samples that were screened for the presence of HHV-8 DNA were 81. The study was able to detect K1, K15 and ORF75 gene in all the 81 archived samples. The extraction of DNA was by use of the Gene Read ${ }^{T M}$ DNA FFPE Kit and detected by nested PCR using Qiagen ${ }^{\circledR}$ Taq PCR Core Kit where us the PCR products were isolated using $1 \%$ agarose gels. The KS gene products were cloned into pTOP V2-TA vector for the sticky-end and sequenced using M13 primers. The study cloned and sequenced 20 samples for each targeted K1, K15 (P) and ORF75 gene. Good sequences result was obtained $50 \%$ (10/20) ORF75, 40\% (8/20) K15(P) and 75\% (15/20) Klgene.Double gene sequences were also detected. The study can authoritatively state that K1,K15 $(P)$ and ORF75 genes sequences for the KS were detected in the archived samples.

Keywords: Kaposi's sarcoma,Human Herpes virus (HHV-8), Genotyping, Sequencing

\section{Introduction}

The DNA sequences for Human herpesvirus-8 (HHV-8) was identified first in a tissue biopsy from a patient who had Acquired immunodeficiency syndrome (AIDS) associated Kaposi's sarcoma ${ }^{(1)}$. An easy way to comply with 
the Recent Science journal paper formatting requirements is to use this document as a template and simply type your text into it. In Uganda sexually transmitted diseases, people living in urban settings, people who are constantly on transit away from home are prone to develop AIDS associated $\mathrm{KS}^{(2)}$. Immunosuppression, low CD4 cell count, duration of time since HIV infection, adherence to antiretroviral treatment are among the risk factors for KS. The use of PCR (Polymerase Chain Reaction) technique to screen for HHV-8 gene can predict the likelihood of on ending up developing $\mathrm{KS}^{(3)}$. Most studies on KS 1 gene involve subjects from Africa and more specifically in East and Central Africa. The KSHV (Kaposi's sarcoma Herpes virus) ORF K1 has been amplified from PBMC (Peripheral blood mononuclear cells) or plasma DNA by use of a nested PCR technique. Among the circulating strains of KSHV, there exist a significant $\mathrm{K} 1$ gene that is diverse ${ }^{(4)}$. A study conducted in Uganda on evolution of HHV-8, K $15 \mathrm{M}$ variant was reported. The sequence analysis of the K15 gene indicated that $\mathrm{P}$ allele was more prominent than $\mathrm{M}$ allele $^{(5)}$. On a whole KS genome, the K15 gene is located on the right and it is involved in signal transduction. The $\mathrm{P}$ allele which is significantly more among people with HHV-8 gene is often associated with all the five K1 subtypes. The KS subtypes A, B and C are known to be associated with rare $\mathrm{M}$ allele and have been reported in parts of Africa not the East Africa. It is worth noting that $\mathrm{K} 15$ allele is unrelated to K1 subtype ${ }^{(6)}$. Kaposi's sarcoma is a persistent infection which is lifelong and is associated with lymphoproliferative disease and tumour. The ORF75 gene is known to play a vital role in viral replication and prodromal viral gene expression ${ }^{(7)}$.

The aim of this study was to detect and determine the circulating $\mathrm{KS}$ genes in the archived tissue samples.

\section{Material and Methods}

Study population. This was a retrospective descriptive study where archived tissue samples were retrieved from the year 2016 to 2013. The tissue samples were formalin fixed paraffin embedded (FFPE) and were sectioned $(10 \mu \mathrm{m})$ using a rotary microtome. Different blades were used per tissue to prevent carryover of DNA and after each tissue section, the surfaces of the microtome were sterilized with DNAZap ${ }^{\mathrm{TM}}$ PCR DNA degradation solutions. Macrogen kit Gene Read DNA FFPE was used for DNA extraction. The Gene Read DNA FFPE removes paraffin and reverses formalin cross-links from the DNA sample before it is bound to the QIAamp Min Elute column. The DNA eluted was ready to be used for nested PCR. Taq PCR Core Kit- Qiagen was used to detect KS genome. Three (K1, K15 and ORF75) gene locus of KSHV were detected using two sets of primers in table 1. The PCR cycling condition of all the three regions were similar and it consisted of 30 number of cycles which entailed; initial denaturation at $94^{\circ} \mathrm{c}$ for 3 minutes, denaturation at $94^{\circ} \mathrm{c}$ for 1 minute, annealing at $63^{\circ} \mathrm{c}$ for 1 minute, extension at $72^{\circ} \mathrm{c}$ for 1 minute and final extension at $72^{\circ} \mathrm{c}$ for 10 minutes. The amplified PCR products were analysed by electrophoresis on a $1 \%$ agarose gel containing ethidiumbromide $(1 \mu \mathrm{l} / \mathrm{ml}$ of agarose solution) and were visualized under ultraviolet light alongside $1 \mathrm{~Kb}$ DNA ladder. A known case of $\mathrm{KS}$ was used as positive control and RNase free water used as a negative control.

Table 1: KSHV sets of Primers used for thenested PCR

\begin{tabular}{|l|l|l|}
\hline \multirow{2}{*}{$\begin{array}{l}\text { Gene } \\
\text { Locus }\end{array}$} & \multicolumn{2}{l|}{ Product } \\
\cline { 2 - 3 } & Size & Primer sequence \\
\cline { 2 - 3 } & 868 & $\begin{array}{l}\text { K1a-f ATGTTCCTGTATGTTGTCTGC } \\
\text { K1a-r AGTACCAATCCACTGGTTGCG }\end{array}$ \\
\hline $\begin{array}{l}\text { K15 } \\
(P)\end{array}$ & 365 & $\begin{array}{l}\text { K1b-f GTCTGCAGTCTGGCGGTTTGC } \\
\text { K1b-r CTGGTTGCGTATAGTCTTCCG }\end{array}$ \\
\cline { 2 - 3 } & $\begin{array}{l}\text { K15P-OF } \\
\text { TGCAGGCTTGGTCATGGGTTAC } \\
\text { K15P-OR } \\
\text { GGGACCACGCTGCAATTAAATG }\end{array}$ \\
\hline ORF75 & 895 & $\begin{array}{l}\text { K15-3C ACGCATACATGTACTGCCAC } \\
\text { K15-4C CTTTGATATTGCCAGTGGTG }\end{array}$ \\
\cline { 2 - 3 } & $\begin{array}{l}\text { KS 1000 CGGTTCGGTGGCATACAGGC } \\
\text { CTGACTACAGAGGGTGTCCCCG }\end{array}$ \\
\cline { 2 - 3 } & 804 & $\begin{array}{l}\text { LGH 2000 GGAAACAGGGTGCTGTG } \\
\text { LGH 2034 CATGGCCTACGACGTCAC }\end{array}$ \\
\hline
\end{tabular}


Cloning and sequencing: PCR products were isolated using $1 \%$ agarose gels. The KS gene products were cloned into pTOP V2-TA vector for the sticky-end and sequenced using M13 primers. The study cloned and sequenced 20 samples for each targeted K1, K15 (P) and ORF75 gene. Three clones were sequenced for each of the sample and the purpose of this was to verify the sequence. Both the forward and reverse PCR products were sequenced. The products of the DNA sequence were aligned using MAFFT version 7. Neighbour joining analysis of the aligned sequences were carried out in MEGA version6 software packages.

\section{Ethical consideration: Ethical approval} (P682/11/2014) was obtained from Kenyatta National Hospital/University of Nairobi

\section{Results}

All the 81 archived tissue samples had the K1, K15 (P) and ORF75 genes detected. Out of the 81 samples that the HHV-8 gene was detected, only 20 samples each for the three $(\mathrm{K} 1, \mathrm{~K} 15(\mathrm{P})$ and ORF75) genes were subjected to cloning. The proceeded with cloning and sequencing for the samples that had been well amplified and gave good gel band using the nested primers in table 1 . Good sequences result was obtained 50\% (10/20) ORF75, 40\% (8/20) K15 (P) and 75\% (15/20) K1gene (Figure 1).It was noted that four samples had double genes detected; sample P57 (Patient 57) had ORF75 gene and K15 (P) gene, sample P17 (Patient 17) had ORF75 gene and K15 (P) gene, sample P28 (Patient 28) had ORF75 gene and K1 gene and sample P25 (Patient 25) had K15 (P) gene and $\mathrm{K} 1$ gene.

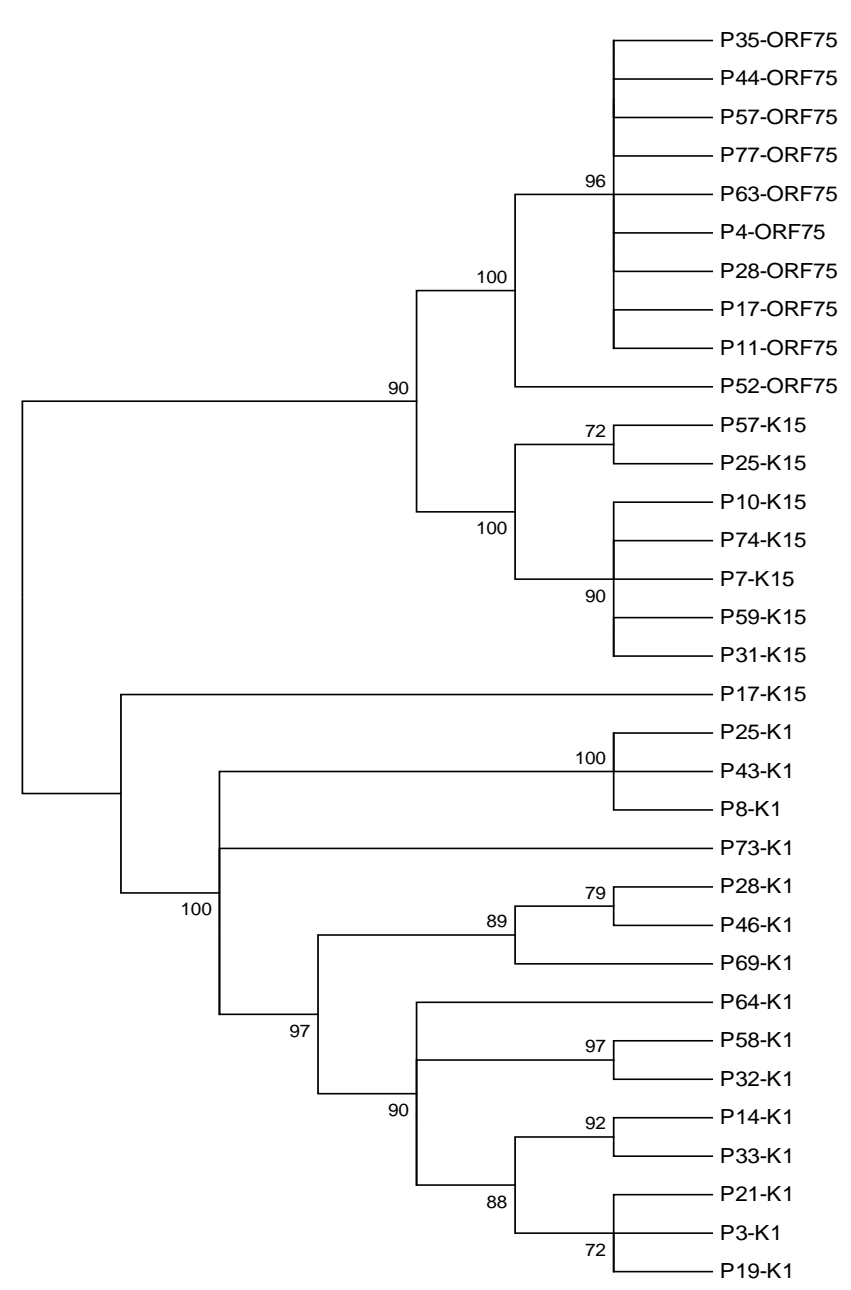

Fig. 1 Thirty-three samples were subjected to bootstrap analysis to create the consensus tree. Neighbour-joining analysis was carried out using MEGA Version 6 software package. Bootstrap above 70 represent significant branching.

\section{Discussion}

In this study we can report that the three (K1, K15 (P) and ORF75) KS genes were successfully detected and can be said to be circulating among patients with AIDS-KS and are living in Nairobi. Earlier studies on KS that have been conducted in Africa have detected HHV-8 genome and noted that their sequences were heterogeneous ${ }^{(8,9,10)}$. A study conducted in Zambia ${ }^{(11)}$ which detected ORF26, ORF75 and K1 gene among its subjects reported that $\mathrm{K} 1$ glycoprotein gene was the most prominent. The findings of the Zambian study are in agreement with this study that also found K1 gene to the most frequent at $75 \%(15 / 20)$ which was later followed by 50\% (10/20) ORF75 gene, $40 \%(8 / 20)$ K15 (P) gene. The K1 subtype A and 
B have also been detected in Zimbabwe ${ }^{(13)}$, in this study the intertype K1 (B) differed with the one conducted in Uganda at a P value of 0.0004 which was considered significant. The K1 gene has also been detected in Botswana and the sequences for this study were obtained from the Bantu and San subjects ${ }^{(3)}$.

This study reported that four samples had double genes detected. These double genes were between ORF75 gene and K15 (P) gene, ORF75 gene and $\mathrm{K} 1$ gene and also K15 (P) gene and K1 gene. A similar finding of double gene detection was also noted in a study outside Africa in Russia (12), where there was diversity on the HHV-8 gene. In the Russian study, there was no correlation between $\mathrm{K} 1$ and K14/1/K15 molecular subtypes and that it was also noted that K5 (M) and K15 (P) genotype can also be observed in the $\mathrm{K} 1$ subtype. Only 40\% ((8/20) samples had K15 (P) gene detected in this study. Similar results of the existence of $\mathrm{K} 15$ (P) have been reported in Uganda where the K15 (P) was noted to be the most predominant compared to the K15 (M) allele (5). The K15 gene exist in two different alleles and the sequence in their amino acids has 70\% divergence. The K15 (P) allele has been reported as the most prevalent and its known to have association with $\mathrm{K} 1$ genes of the subtype A, B, C and D. The K15 (M) allele is less predominant and has not been reported to have any form of association with the rare subtype $\mathrm{D}^{(14)}$. Reports from previous studies that looked at K15 gene used PCR technique to the two ( $\mathrm{P}$ and $\mathrm{M}$ ) alleles $^{(15)}$. The $\mathrm{K} 15(\mathrm{M})$ allele has been reported to be rare in Southern, Central and Westparts of Africa ${ }^{(9)}$, however there has been a single case where it was reported in a 70-year-old patient from Uganda ${ }^{(16)}$.

In Botswana ORF75 sequence were amplified from their subjects, clustered together later they showed that they were aligned to subtype B and subtype C. In South Africa, type N and Q of the ORF75 sequences have been reported in KS strains ${ }^{(3)}$. In our results we were only detecting the existence of the ORF75 gene and its sequences and were able to report that 50\% (10/20) ORF75 genes. The only consistent results in our study with those done in Botswana and South Africa is that we were both able to detect the ORF75 gene sequences in our study participant, however in their studies they went a notch higher and did divergence in the ORF75 gene.

Before the advent of HIV and AIDS African endemic KS was the most prevalent in East and Central Africa, however the AIDS pandemic altered the distribution of $\mathrm{KS}$ and tumour associated with it become the most prevalent in sub-Saharan Africa ${ }^{(17,18)}$.

\section{Conclusion and Recommendation}

$\mathrm{K} 1, \mathrm{~K} 15$ (P) and ORF75 genes for the KS were detected in the archived samples. The three genes are in circulation among the population in Nairobi Kenya. There is need to conduct a study on genetic diversity on the AIDS-KS subtypes.

\section{Acknowledgement}

We acknowledge all the authors in this manuscript and their contribution towards the success of this study. An extended gratitude id channelled to Kenya National Hospital/University of Nairobi for granting us with Ethical approval for this study.

Sources of support: No grant or any form of financial aid

\section{References}

1. Chang Y, Cesarman E, Pessin MS, Lee F, Culpepper J, Knowles DM, Moore PS. Identification of herpesvirus-like DNA sequences in AIDS-associated Kaposi's sarcoma. Science-AAAS-Weekly Paper Edition. 1994 Dec 16;266(5192):1865-9.

2. Ziegler JL, Newton R, Katongole-Mbidde E, Mbulataiye S, De Cock K, Wabinga H, Mugerwa J, Katabira E, Jaffe H, Parkin DM, Reeves G. Risk factors for Kaposi's sarcoma in HIV-positive subjects in Uganda. Aids. 1997 Nov 11;11(13):161926. 
3. Whitby D, Boshoff C, Hatzioannou T, Weiss RA, Schulz TF, Howard MR, Brink NS, Tedder RS, Tenant-Flowers M, Copas A, Suggett FE. Detection of Kaposi sarcoma associated herpesvirus in peripheral blood of HIV-infected individuals and progression to Kaposi's sarcoma. The lancet. 1995 Sep 23;346(8978):799-802.

4. Zong JC, Ciufo DM, Alcendor DJ, Wan X, Nicholas J, Browning PJ, Rady PL, Tyring SK, Orenstein JM, Rabkin CS, Su IJ. High-level variability in the ORF-K1 membrane protein gene at the left end of the Kaposi's sarcoma-associated herpesvirus genome defines four major virus subtypes and multiple variants or clades in different human populations. Journal of virology. 1999 May 1;73(5):4156-70.

5. Kakoola DN, Sheldon J, Byabazaire N, Bowden RJ, Katongole-Mbidde E, Schulz TF, Davison AJ. Recombination in human herpesvirus-8 strains from Uganda and evolution of the K15 gene. Journal of General Virology. $2001 \quad$ Oct 1;82(10):2393-404.

6. Poole LJ, Zong JC, Ciufo DM, Alcendor DJ, Cannon JS, Ambinder R, Orenstein JM, Reitz MS, Hayward GS. Comparison of genetic variability at multiple loci across the genomes of the major subtypes of Kaposi's sarcoma-associated herpes virus reveals evidence for recombination and for two distinct types of open reading frame K15 alleles at the right-hand end. Journal of virology. 1999 Aug 1;73(8):6646-60.

7. Full F, Jungnickl D, Reuter N, Bogner E, Brulois K, Scholz B, Stürzl M, Myoung J, Jung JU, Stamminger T, Ensser A. Kaposi's sarcoma associated herpesvirus tegument protein ORF75 is essential for viral lytic replication and plays a critical role in the antagonization of ND10- instituted intrinsic immunity. PLoS pathogens. 2014 Jan 16;10(1):e1003863.

8. Alagiozoglou L, Sitas F, Morris L. Phylogenetic analysis of human herpesvirus- 8 in South Africa and identification of a novel subgroup. Journal of General virology. 2000 Aug 1;81(8):2029-38.

9. Lacoste V, Judde JG, Briere J, Tulliez M, Garin B, Kassa-Kelembho E, Morvan J, Couppié P, Clyti E, Vila JF, Rio B. Molecular epidemiology of human herpesvirus 8 in Africa: both B and A5 K1 genotypes, as well as the $\mathrm{M}$ and $\mathrm{P}$ genotypes of K14. 1/K15 loci, are frequent and widespread. Virology. 2000 Dec 5;278(1):60-74.

10. Zong J, Ciufo DM, Viscidi R, Alagiozoglou L, Tyring S, Rady $\mathrm{P}$, Orenstein J, Boto W, Kalumbuja H, Romano N, Melbye M. Genotypic analysis at multiple loci across Kaposi's sarcoma herpesvirus (KSHV) DNA molecules: clustering patterns, novel variants and chimerism. Journal of clinical virology. 2002 Jan 1;23(3):119-48.

11. Kasolo FC, Monze M, Obel N, Anderson RA, French C, Gompels UA. Sequence analyses of human herpesvirus- 8 strains from both African human immunedeficiency virus-negative and-positive childhood endemic Kaposi's sarcoma show a close relationship with strains identified in febrile children and high variation in the K1 glycoprotein. Journal of General Virology. 1998 Dec 1;79(12):3055-65.

12. Kadyrova E, Lacoste V, Duprez R, Pozharissky K, Molochkov V, Huerre M, Gurtsevitch V, Gessain A. Molecular epidemiology of Kaposi's sarcoma associated herpesvirus/human herpesvirus 8 strains from Russian patients with classic, posttransplant, and AIDS associated Kaposi's sarcoma. Journal of medical virology. 2003 Dec 1;71(4):54856. 
13. White T, Hagen M, Gudza I, White IE, Ndemera B, Gwanzura L, Borok M, Campbell TB. Genetic diversity of the Kaposi's sarcoma herpesvirus K1 protein in AIDS-KS in Zimbabwe. Journal of Clinical Virology. 2008 Jun 30;42(2):16571.

14. Hayward GS. KSHV strains: the origins and global spread of the virus. InSeminars in cancer biology 1999 Jun 1 (Vol. 9, No. 3, pp. 187-199). Academic Press.

15. Meng YX, Spira TJ, Bhat GJ, Birch CJ, Druce JD, Edlin BR, Edwards R, Gunthel C, Newton R, Stamey FR, Wood C. Individuals from North America, Australasia, and Africa are infected with four different genotypes of human herpesvirus 8. Virology. 1999 Aug 15;261(1):106-19.

16. Ziegler JL, Katongole-Mbidde E. Kaposi's sarcoma in childhood: an analysis of 100 cases from Uganda and relationship to HIV infection. International Journal of Cancer. 1996 Jan 17;65(2):200-3.

17. Wabinga HR, Mugerwa JW, Parkin DM, Wabwire-Mangen F. Cancer in Kampala, Uganda, in 1989-91: changes in incidence in the era of AIDS. International Journal of Cancer. 1993 Apr 22;54(1):26-36.

18. Sitas F, Newton R. Kaposi's sarcoma in South Africa. JNCI Monographs. 2000

Dec 1;2000(28):1-4. 